\title{
Constitutionalising the International Legal Order through Case Law? Judgment No 238/2014 from the Italian Constitutional Court
}

\author{
Maria Elena Gennusa*
}

\begin{abstract}
Judgment No 238/2014 of the Italian Constitutional Court held that the customary international law on State immunity, insofar as it covers war crimes and crimes against humanity, has not entered the domestic legal order, and therefore has no effect therein. It also declares unconstitutional Article 1 of Law No 848/1957 and Article 3 of Law No 5/2013, which aimed to ensure the compliance of Italy with the decisions of the International Court of Justice. In its judgment, the $\mathrm{CC}$ asserts its aspiration to 'contribute to a desirable-and desired by many-evolution of international law itself'. By analysing the legal reasoning of the CC, this paper infers the real purpose behind Judgment No 238/2014 and evaluates the appropriateness of the approach used to reach its objectives.
\end{abstract}

\section{Keywords}

State immunity, Italian Constitution, Counter-limits, Italian Constitutional Court, Dualism

\section{Judgment No 238/2014 in context: The Italian saga of state immunity and war crimes}

On 22 October 2014 the Italian Constitutional Court (CC) delivered its now wellknown Judgment No $238^{1}$ on State immunity and war crimes. This represented a crucial moment in the so-called 'Ferrini saga', which concerns the long-standing

* Associate Professor of Constitutional Law at the University of Pavia, Italy. The author is grateful to Stefania Ninatti, Lorenza Violini, Maurizio Arcari, Antonia Baraggia and Paolo Zicchittu for their insightful observations and valuable suggestions. Thanks are also due to the anonymous CJICL reviewers for their critical comments on the first draft of this article and to Massimo Lando for his patient and accurate help in editing the final version. The usual disclaimers apply.

1 Italian Constitutional Court, Judgment No 238 (2014) (Judgment No 238/2014). 
issue of Germany's refusal to pay compensation for damage to the victims of Nazi atrocities carried out on Italian soil during the final stages of World War II.

Beginning with the Ferrini $v$ Federal Republic of Germany decision of 11 March 2004 by the Court of Cassation (Corte di Cassazione), ${ }^{2}$ the Italian courts affirmed their jurisdiction over the question of compensation, even though the respondent in civil proceedings was a foreign State. The Court of Cassation did not, however, decide to assert its jurisdiction over a foreign State with the aim of deliberately disregarding the international customary norm on State immunity. Instead, the Court had presumed that jus cogens (and, therefore, the protection of some essential human rights) had taken on such importance in international law as to make immunity in cases like the one at stake inapplicable under international law. ${ }^{3}$ Under the Court's interpretation, an exception to immunity for war crimes and crimes against humanity was 'already embedded in the international legal order' and all that remained was to bring it to light. ${ }^{4}$

This assertion of jurisdiction by the Italian courts was subsequently challenged by Germany before the International Court of Justice (ICJ). In Jurisdictional Immunities of the State (Germany v Italy: Greece intervening), ${ }^{5}$ the ICJ found against Italy and ordered it to ensure that, "by enacting appropriate legislation, or by resorting to other methods of its choosing, the decisions of its courts infringing the immunity of Germany 'cease to have effect. ${ }^{6}$ Following a substantial, albeit somewhat selective, survey of State practice and opinio juris, ${ }^{8}$ the ICJ categorically excluded the existence of an exception to the rule of State immunity from civil suits relating to acta jure

Italian Court of Cassation, Ferrini v Repubblica Federale di Germania (2004) ILDC 19; translated in (2004) 128 ILR 658 (Judgment No 5044/2004).

3 For more on this judgment, see Pasquale De Sena \& Francesca De Vittor, 'State Immunity and Human Rights: The Italian Court Decision on the Ferrini Case' (2005) 16 EJIL 89.

Italian Court of Cassation, Repubblica Federale di Germania v Mantelli (2008) ILDC 1037 [11] (emphasis added); see also Carlo Focarelli, 'Federal Republic of Germany v Giovanni Mantelli and Others' (2009) 103 AJIL 122, 125 and sourced from Filippo Fontanelli, 'Criminal Proceedings Against Albers' (2013) 107 AJIL 632.

5 Jurisdictional Immunities of the State (Germany v Italy; Greece intervening) (Judgment) [2012] ICJ Rep 99.

6 ibid [139(4)].

7 See, eg, Riccardo Pavoni, 'An American Anomaly? On the ICJ's Selective Reading of the United States Practice in Jurisdictional Immunities of the State' (2012) 21 Italian YIL 143.

8 The survey of State practice and opinio juris takes a large part of Judgment Jurisdictional Immunities [55]-[97]; with regard to the territorial tort principle, see more specifically [62][69]; to the argument concerning the gravity of the violations, [80]-[91]; to the relationship between jus cogens and the rule of immunity, see [92]-[97]. 
imperii carried out by armed forces during conflicts in the territory of the forum State. ${ }^{9}$ The ICJ made this exclusion for cases involving war crimes or crimes against humanity as well as cases involving victims who were otherwise only able to seek a remedy in the forum State.

The reaction of the Italian Parliament to the ICJ's decision was immediate and deferential. With unusual swiftness, the Italian Parliament approved Law No 5 of 14 January 2013 (Law No 5/2013), ${ }^{10}$ authorising accession to the United Nations Convention on Jurisdictional Immunities of States and Their Property. ${ }^{11}$ Article $3^{12}$ of Law No 5/2013 was drafted to ensure full compliance with the ICJ's Jurisdictional Immunities judgment, ${ }^{13}$ and to 'avoid unfortunate situations such as those created by the dispute before the Court of The Hague. ${ }^{14}$ The Court of Cassation-in Criminal Proceedings against Albers and Others ${ }^{15}$-no longer insisted on the original approach of its Ferrini judgment ${ }^{16}$ and acknowledged Germany's immunity.

This deferential approach to the ICJ's decision, however, was not replicated by the Italian judiciary. On 21 January 2014 the Tribunal of Florence, a first instance court, faced with yet another claim for compensation for harm suffered by Italian citizens captured in Italy and deported to concentration camps, ${ }^{17}$ requested a

9 ibid [107]-[108].

10 The Chamber of Deputies and the Senate of the Republic, Accession of the Italian Republic to the United Nations Convention on the Immunity Courts of States and their Property, Law No 5 of 13 January 2013, (Law No 5/2013) <http://www.normattiva.it/uri-res/ N2Ls?urn:nir:stato:legge:2013;5> accessed 22 January 2015.

11 (adopted 2 December 2004 UNGA Res A/59/38).

12 Law No 5/2013 (n 10) art 3, para 5.1, '1. For the purposes of Art 94, para 1, of the United Nations Charter, (...) when the ICJ, in a judgment settling a dispute in which Italy is a party, excluded the possibility of subjecting certain specific conducts of another state to civil jurisdiction, the judge before whom a dispute concerning the same conducts has been brought shall declare ex officio at any stage of the proceedings their lack of jurisdiction, even when they have already rendered a final judgment on a procedural matter in which they upheld their jurisdiction. 2 . The final judgments contrary to the judgment of the ICJ referred to in para 1, even when the latter has been passed subsequently, can be impugned for revision for lack of civil jurisdiction'.

13 Jurisdictional Immunities (n 5).

14 House of Representatives, XVI Legislature, Commissions Service, Foreign and Community Affairs, Ratification of the United Nations Convention on Jurisdictional Immunities of States and Their Property, (26 September 2012, AC No. 5434/XVI) <http://documenti.camera.it/ leg16/dossier/testi/SA5434.htm> accessed 10 March 2015.

15 Italian Court of Cassation, Military Prosecutor v Albers and others and Germany (2012) ILDC 1921.

16 Judgment No 5044/2004 (n 2).

17 Simoncioni and Others $v$ Germany, Application No 8879/2011 (Tribunal of Florence). 
preliminary ruling by the $\mathrm{CC}$ concerning the conformity of the following legal norms with the Italian Constitution: (1) the domestic norm incorporating into the Italian legal order the international custom on State immunity from civil jurisdiction as interpreted by the ICJ in its Germany $v$ Italy judgment; ${ }^{18}$ (2) Article 1 of Law No 848 of 17 August 1957,, (Law No 848/1957) which gave 'full execution' to the Charter of the United Nations ${ }^{20}$ by obliging the national judge to comply with the ICJ's judgments; and (3) Article 3 of Law No 5/2013, which had incorporated the ICJ's Jurisdictional Immunities judgment ${ }^{21}$ into the domestic order. In all three questions, the constitutional norms potentially affected were Articles 2 and 24 of the Italian Constitution, ${ }^{22}$ the former aiming to protect inviolable human rights ${ }^{23}$ and the latter guaranteeing the right to have recourse to a judge for the protection of rights and legitimate interests. ${ }^{24}$

The CC's response to these questions of constitutionality was clear-cut. First, the customary rule of international law on State immunity for war crimes and crimes against humanity 'has not entered the Italian legal order and, therefore, does not have any effect therein. ${ }^{25}$ Second, the CC held that Article 3 of Law No 5/2013 and Article 1 of Law No 848/1957 were unconstitutional, the latter exclusively to the extent that it obliges an Italian judge to comply with the Jurisdictional Immunities judgment. $^{26}$

Jurisdictional Immunities (n 5).

The Chamber of Deputies and the Senate of the Republic, Statute Execution of the United Nations, Law No 848 of 17 August 1957 <http://www.normattiva.it/uri-res/ N2Ls?urn:nir:stato:legge:1957-08-17;848> accessed 16 February 2015.

Charter of the United Nations (adopted 26 June 1945, entered into force 24 October 1945) 892 UNTS 119.

Jurisdictional Immunities (n 5).

Constitution of the Italian Republic. Official English translation by the Senate of the Italian Republic at <www.senato.it/documenti/repository/istituzione/costituzione_inglese.pdf> accessed 22 February 2015 (hereafter Italian Constitution).

Italian Constitution (n 22) art 2: ' $[\mathrm{t}]$ he Republic recognises and guarantees the inviolable rights of the person, both as an individual and in the social groups within which human personality is expressed. The Republic expects that the fundamental duties of political, economic, and social solidarity be fulfilled'.

Italian Constitution (n 22) art 24: '[a]nyone may bring cases before a court of law in order to protect their rights under civil and administrative law. Defence is an inviolable right at every stage and instance of legal proceedings.

Judgment No 238/2014 (n 1) [3.5].

ibid paras 1, 2 and 3 of the operative part of the Judgment. 


\section{Challenging, deferential and confusing: The CC's attitude towards international law}

Although Judgment No $238 / 2014^{27}$ has stirred scholarly debate relating to both constitutional and international law, ${ }^{28}$ the aim of this paper is to analyse the CC's decision only from the perspective of the Court's attitude towards international law. This analysis is not, however, a straightforward undertaking. While the CC makes the final objective of Judgment No 238/2014 relatively clear, ${ }^{29}$ its attitude towards international law and the overall intentions of the judgment lack such clarity. Is it the aim of the CC to challenge international law and the ICJ, or, rather, does the $\mathrm{CC}$ mean to show deference to the authority of the latter? What is the purpose of the CC proclaiming that it intends to 'contribute to a desirable-and desired by many-evolution of international law itself'?

On closer scrutiny, the legal reasoning deployed by the CC in Judgment No $238 / 2014$ can be seen to be dualistic, in that it is both deferential and subversive, depending on the perspective chosen. This dualistic approach is seen in the wellknown Court of Justice of the European Union (CJEU) judgment, Kadi $I^{31}$ - to which Judgment No 238/2014 expressly refers. ${ }^{32}$ In the Kadi I judgment, the CJEU refused to follow the UN Security Council (SC), while simultaneously affirming that the

ibid.

28 Literature on this judgment is extensive, with recent commentators including Riccardo Pavoni, 'Simoncioni v Germany' (2015) 109 AJIL 400; Massimo Lando, 'Intimations of Unconstitutionality: The Supremacy of International Law and Judgment 238/2014 of the Italian Constitutional Court' (2015) 78 MLR 1028; see also Francesco Francioni, 'From Deference to Disobedience: The Uncertain Fate of Constitutional Court Decision No 238/2014' (2015) 24 Italian YIL 1; Riccardo Pisillo Mazzeschi, 'Access to Justice in Constitutional and International Law: The Recent Judgment of the Italian Constitutional Court' (2015) 24 Italian YIL 7; Michael Bothe, 'The Decision of the Italian Constitutional Court Concerning the Jurisdictional Immunities of Germany' (2015) 24 Italian YIL 25; Giuseppe Cataldi, 'A Historic Decision of the Italian Constitutional Court on the Balance Between the Italian Legal Order's Fundamental Values and Customary International Law' (2015) 24 Italian YIL 37; Paolo Palchetti, 'Can State Action on behalf of Victims be an Alternative to Individual Access to Justice in Case of Grave Breaches of Human Rights?' (2015) 24 Italian YIL 53.

See section 3, below.

30 Judgment No 238/2014 (n 1) [3.3].

31 Joined Cases C-402/05 P and C-415/05 P Yassin Abdullah Kadi and Al Barakaat International Foundation $v$ Council of the European Union and Commission of the European Communities [2008] ECR I-6351 (Kadi I).

Judgment No 238/2014 (n 1) [3.4]. 
annulment of the European Union (EU) measure implementing a SC resolution did not entail 'any challenge to the primacy of that resolution in international law. ${ }^{33}$ The result in Kadi I was extremely challenging-the SC resolution had been deprived of any effect within the EU legal order-but this outcome had been pursued without explicitly contesting the validity of the resolution on the international plane. Similarly, ${ }^{34}$ in Judgment No 238/2014 the CC used dualism and the separation between legal orders in order to pay lip service to the ICJ with regard to the role played by it in the international order, while at the same time disobeying an international obligation by asserting the primacy of domestic law.

On the one hand, the CC's decision could be interpreted as deferential. ${ }^{35}$ That is, the CC refused to scrutinise the interpretation of the norm on State immunity supplied by the ICJ on the basis that the norm is international in character, and therefore outside the Italian system. ${ }^{36}$ In making its decision, the CC invoked the principle of conformity, which holds that a principle may only be understood as it exists in the order in which it originated-namely the international legal order. ${ }^{37}$ That is, the CC held that the ICJ, in interpreting international law, is 'particularly qualified and does not allow further examination by national governments and/ or judicial authorities, including this Court. ${ }^{38}$ In this sense, the CC claimed that it was limited simply to acknowledging that, at the international level, the immunity rule covers even the most serious of crimes, such as war crimes or crimes against humanity, but that the rule did not have any effect at the domestic level. ${ }^{39}$

On the other hand, the CC asserts resolutely that, while the ICJ has authority to interpret international law, the CC is entitled to decide whether international norms interpreted by the ICJ can be applied within the domestic legal order. ${ }^{40}$ In Italy, the role played by international custom within the domestic order is regulated under Article 10 of the Constitution, which provides that ' $[t]$ he Italian legal order

Kadi I (n 31) [288].

One difference is that, while the CC looked directly at international custom (in order to evaluate the admissibility of its entry into the domestic order), the CJEU focused its review on the Community regulation implementing the SC resolution.

Although the CC did not entirely cease its criticisms of the ICJ's line of reasoning, for example, it commented that 'it would indeed be difficult to identify how much is left of a right if it cannot be invoked before a judge in order to obtain effective protection'. See Judgment No 238/2014 (n 1) [3.4].

Judgment No 238/2014 (n 1) [3.1].

ibid.

ibid.

ibid [3.5].

ibid [3.3]. 
conforms to the generally recognised rules of international law. ${ }^{41}$ Article 10 introduces a mechanism of automatic adjustment of the national order to generally recognised international norms. This means that customary international rules are incorporated into the domestic system as soon as they are formed, acquiring the same rank as the norms of the Italian Constitution. In Judgment No 238/2014, however, the CC states clearly that this mechanism cannot allow for the automatic integration of all customary norms without distinction. ${ }^{43}$ Article 10 is a selective compliance mechanism that opens the doors of the Italian legal system only to those external norms not conflicting with the highest principles of the Italian Constitution. ${ }^{44}$ If such a conflict arises, international customary norms cannot enter the domestic legal order regardless of whether they pre-date the entry into force of the Italian Constitution. ${ }^{45}$ Such a conflict is precisely what happened in Judgment No 238/2014. Evidently, the CC's deference to the ICJ ceases here because the outcome achieved by concluding that the international norm does not exist within the domestic order is highly subversive.

A comparison of Judgment No 238/2014 with the earlier Ferrini decision handed down by the Court of Cassation ${ }^{46}$ is illuminating. The consequence of both judgments-namely, the non-application within the domestic order of the

41 Italian Constitution (n 22) art 10.

42 Judgment No 238/2014 (n 1).

43 ibid [3.4].

44 ibid.

45 ibid [2.1]. The CC achieved this outcome by relying on its Judgment No 1 (1956), in which the Court stated that " $\mathrm{t}$ ] he assumption that the new notion of "unconstitutionality" concerns only laws subsequent to the Constitution, and not laws prior to it, cannot be accepted' (translation provided by the author; emphasis added), and on Judgment No 48 (1979), concerning the jurisdictional immunity of diplomatic officials. The reference to the latter is more controversial, because, if it is accepted that, in it, the CC examined the customary norm on immunity of State agents, the Court also clearly affirmed therein that it should be noted, more generally, with regard to the generally recognised norms of international law that came into existence after the entry into force of the Constitution, that the mechanism of automatic incorporation envisaged by Article 10 of the Constitution cannot allow the violation of the fundamental principles of our constitutional order, as it operates in a constitutional system founded on popular sovereignty and on the rigidity of the Constitution' (Judgment No 48 (1979) [3], translation provided by the CC in the text of Judgment No. 238/2014; emphasis added), so seemingly admitting judicial review only over customs crystallised after the entry into force of the Constitution. Therefore, according to many authors, in Judgment No 238/2014, through relying on Judgment No 48 (1979), the CC definitively overruled its precedent (see also Italian Constitutional Court, Judgment No 73 (2001)); see, eg, Massimo Luciani, 'I controlimiti e l'eterogenesi dei fini' (2015) 1 Questione Giustizia 84, 87-88. Judgment No 5044/2004 (n 2). 
immunity rule when war crimes or crimes against humanity are at stake-was the same. In the Ferrini judgment, this outcome was achieved because the Court of Cassation was persuaded that immunity for war crimes and crimes against humanity were no longer applicable under international law. ${ }^{47}$ Accordingly, the Court of Cassation rejected the application of the immunity rule domestically. Conversely, in Judgment No 238/2014, while the CC recognised the application of the immunity rule under international law, it chose to disregard an international obligation incumbent upon Italy in the name of the domestic Constitution. Thus, 'the major challenge posited by the reasoning of the CC lies in the idea that a State can maintain some leeway, by invoking some essential principles of its internal (constitutional) order, in deciding how and when international law obligations can be admitted or not. ${ }^{48}$ It is also perceptible that the dualism employed in Judgment No 238/2014 led 'to a sort of murder of international law through municipal law ${ }^{49}$ by undermining and delegitimising the authority of the ICJ. ${ }^{50}$

\section{The objective of Judgment No 238/2014: The protection of the primacy of the Italian Constitution}

According to the CC, the scope of immunity, as ascertained by the Jurisdictional Immunities judgment, ${ }^{51}$ would necessitate a total sacrifice of the right to judicial protection of the Constitution. Judgment No 238/2014 represents a concrete 
application of the CC's 'doctrine of counter-limits', traditionally invoked by the CC since the 1970s when dealing with issues relating to the applicability of external norms in the domestic legal order.

According to the CC's jurisprudence, 'counter-limits' are supreme constitutional principles, respect for which is an inescapable condition for the openness of the domestic legal order to external legal orders. ${ }^{52}$ Article 11 of the Italian Constitution provides that 'Italy agrees, on condition of its equality with other States, to the limitations of sovereignty that may be necessary to a world order ensuring peace and justice among the Nations. ${ }^{53}$ 'Counter-limits' may be considered, accordingly, as limits that the Italian State sets in order to safeguard its sovereignty by means of external legal rules. Italy is permitted by the Constitution to limit its sovereignty only as long as this limitation does not threaten core constitutional principles. ${ }^{54}$ The CC originally drafted its 'counter-limits doctrine' with regard to the relationship between domestic and EU law. The 'doctrine of counter-limits' was established in Judgment No 183 of 18 December 1973 as follows:

On the basis of Article 11, limitations of sovereignty have been allowed solely for the attainment of the goals indicated there; and it must therefore be ruled out that those limitations concretely delineated in the Treaty of Rome (...) may in any case entail for the organs of the Community an inadmissible power of violating the basic principles of our constitutional order, or the inalienable rights of the human being. And it is obvious that, should this happen, the guarantee of the judicial review of this Court would always be ensured regarding the long-lasting compatibility of the Treaty with the aforesaid fundamental principles. ${ }^{55}$

Remarkably, the same 'counter-limits' to external law are also limits to the internal parliamentary power of constitutional reform, as the CC has often reiterated, beginning with Judgment No 1146 of 15 December $1988 .{ }^{56}$ However, the CC has not concretely made use of 'counter-limits' against EU law so far. Indeed, the CC applied them for the first time in Judgment No 238/2014, when the CC prevented State immunity from the jurisdiction of foreign courts from entering into the 284/2007, No 80/2011. Global Context (OUP 2016) 215-16. Italian Constitutional Court, Judgment No 1146 (1988). 
domestic legal system in order to protect the supreme values of the Constitution. This sheds some light on the ultimate objective of Judgment No 238/2014: the protection of the primacy of the Constitution.

Kolb has argued that 'dualism is protective of State sovereignty. ${ }^{57}$ This notion can also be applied in the present discussion. Since constitutional sovereignty is an essential component of State sovereignty, the protection of the latter can be seen to rest on safeguarding the integrity of the former. Accordingly, the dualism employed in Judgment No 238/2014 may be interpreted as protecting the sovereignty of the Italian State through the guarantee of the primacy of its domestic Constitution. This approach, however, only partially captures the many facets of the complex relationship between the sovereignty of the State and the sovereignty of the Constitution. That is, within the domestic legal order, the primacy of the Constitution is different from, and superior to, the supreme political will of the sovereign people as expressed through the political institutions of the State. Article 1 of the Italian Constitution proclaims that 'sovereignty belongs to the People and is exercised by the People in the forms and within the limits of the Constitution. ${ }^{58}$ This means that, under a rigid Constitution, ordinary legislation encounters an insuperable limit in the general observance of the Constitution. It also means that, as noted above, even a constitutional amendment cannot alter the essential constitutional core as expressed in the most fundamental choices taken by the constituent power. That core is, therefore, untouchable and non-modifiable, even by the sovereign people.

In this sense, the protection of the primacy of the Constitution may be seen as the ultimate aim of Judgment No 238/2014. This protection effectively allowed the CC both to use 'counter-limits' against the entry of the customary norm of State immunity $^{59}$ and also to quash two laws aimed at complying with the Jurisdictional Immunities judgment. ${ }^{60}$ In this regard, the CC is in open conflict with other Italian institutions-a conflict likely to continue after Judgment No 238/2014, ${ }^{61}$ and which may not be resolved even if the laws quashed by the $\mathrm{CC}$ were passed as constitutional

61 On 25 November 2014, just one month after Judgment No 238/2014, the Italian Government reiterated its willingness to deposit its declaration of acceptance of the ICJ's compulsory jurisdiction under the Statute of the International Court of Justice (adopted 26 June 1945, entered into force 24 October 1945) 1 UNTS 16, art 36(2). See Francioni (n 28) 2. 
laws. Indeed, as they violate the same highest constitutional principles considered to be 'counter-limits' to external norms, they would be declared unconstitutional. Interestingly, if the protection of the primacy of the Italian Constitution can be found to be the ultimate objective of Judgment No 238/2014, the second questionwhether the CC intended to challenge international law or to be deferential to itbecomes irrelevant. The Court seemingly set out solely to protect the constitutional core, irrespective of the manner or the means.

\section{Constitutionalising the international order through case law?}

That said, the CC did declare its intention to 'contribute to a desirable - and desired by many-evolution of international law itself. ${ }^{62}$ Judgment No 238/2014 seems situated within an emerging judicial trend in which domestic courts reveal a general propensity towards disregarding international obligations when the protection of fundamental human rights is at stake. ${ }^{63}$ This inclination is often interpreted as a manifestation of the will of courts to constitutionalise the international legal order, or for the international legal order to evolve towards a Constitution-oriented structure in which some basic values (for example, the observance of the rule of law and the protection of fundamental rights) prevail. ${ }^{64}$ However, given the considerations above, is the approach pursued by the CC in Judgment No 238/2014 an appropriate one with which to constitutionalise the international legal order? Moreover, is the constitutionalisation of the international legal order really an objective of the CC?

The CC challenged State immunity law by looking solely at the Italian Constitution. Further, it condemned the rule of State immunity, if only in cases of the most serious crimes, exclusively on the basis of interests that the Constitution renders worthy of protection and in light of the consequences of immunity on

62 Judgment No 238/2014 (n 1).

63 See, in particular, Kadi I (n 31); see also Al-Jedda v United Kingdom (App No 27021/08) [2011] ECHR 1092; Nada $v$ Switzerland (App No 10593/08) [2012] ECHR 1691.

64 See, eg, Marise Cremona et al (eds), Reflections on the Constitutionalisation of International Economic Law (Martinus Nijhoff 2014); Alexander Orakhelashvili (ed), Research Handbook on the Theory and History of International Law (Edward Elgar 2011); Jan Klabbers, Anne Peters and Geir Ulfstein (eds), The Constitutionalization of International Law (OUP 2009); Esme Shirlow, 'Taking Stock: Assessing the Implications of the Kadi Saga for International Law and the Law of the European Union' (2014) 15 MJIL 2. 
supreme constitutional rights. However, the Court could have more fruitfully contextualised the Italian Constitution within the international legal framework by exalting the universality of some of the values that, while enshrined in the Constitution, are equally embedded in international law. For instance, the right to judicial protection at stake in Judgment No 238/2014 is also protected under numerous international instruments, such as the European Convention on Human Rights (Article 6), the International Covenant on Civil and Political Rights (Article 14) and the Universal Declaration of Human Rights (Article 14). Nevertheless, only once does the CC admit that 'there is little doubt that the right to adjudicate and to affect judicial protection of inviolable rights is one of the greatest principles of legal culture in democratic systems of our times. ${ }^{65}$ In all other instances, the CC depicts this right as a distinctive trait of the Italian Constitutional 'identity. ${ }^{66}$ Furthermore, highlighting tenets common to domestic and international law does not necessarily mean a rejection of dualism. It simply means acknowledging that legal orders, although separate and distinct, may share some fundamental values upon which the foundation for positive development can be fruitfully laid. The CC could have admitted such a commonality of values while continuing to follow its traditional dualistic approach.

Moreover, it is certainly true that the primary task of the CC is to exercise its authority over domestic constitutional issues within the limits fixed by the Constitution. Nonetheless, the CC might have emphasised the universal character of the domestic values that are at the heart of the Italian Constitution. Giving weight to this universal character could have been of great significance in international law, especially in the light of the gravity of the crimes for which immunity was claimed.

Responsibility for the crimes discussed in Judgment No 238/2014 had been admitted without objection by Germany, while those claiming damages were undoubtedly the victims of those crimes (or their descendants). However, compensation for these crimes has been repeatedly denied. ${ }^{67}$ The injustice of the situation was so obvious that even the ICJ expressed 'surprise and regret. ${ }^{68}$ International law can no longer fail to tackle situations of this kind. Immunity alone has already been shown to be inadequate in cases like this, but other

ibid.

For some details concerning German civil proceedings where compensation was denied, see the ECtHR case concerning Associazione Nazionale Reduci dalla Prigionia, dall'Internamento e dalla Guerra di Liberazione and 275 Others $v$ Germany (Application No 45563/04).

Jurisdictional Immunities (n 5) [99], [143]. 
approaches may be viable. For instance, immunity could be declared inapplicable when war crimes are at issue and no alternative remedies to ensure compensation exist. Otherwise, other mechanisms could be established under international law to operate jointly with immunity in order to prevent the most serious violations of fundamental procedural rights. A solution needs to be found at the international level, and it is hoped that the CC might have contributed to identifying the need for such a solution. The CC missed this opportunity, however, by maintaining an exclusively inward-looking perspective.

The CC's inward-looking focus raises doubts about the potential of Judgment No 238/2014 to constitutionalise international law. A rule such as that of immunity, which is universal (albeit controversial), is likely to change in line with the protection of values that are universal as well. Therefore, no serious attempt to constitutionalise the international legal order can be achieved by limiting discussion to the consideration of only one national Constitution. Accordingly, the choice to base its decision on constitutional law grounds casts a shadow on the real intention of the CC. Does the CC really seek to constitutionalise international law? Or, is the CC simply interested in deciding a constitutional law case, with a distant hope that this might also lead to a development in international law? It has since been conjectured that the CC 'essentially gave up trying to change the state of injustice registered at the international level, and limited itself to preserve the domestic order from the effect of this injustice. ${ }^{69}$

Doubts remain, nonetheless. First, the CC referred to the CJEU's Kadi I judgment, ${ }^{70}$ which could bring about some development at the international level, ${ }^{71}$ while simultaneously maintaining a similarly dualistic approach and inwardlooking perspective. The Court also relied on its own previous decision, Judgment No $232 / 1989,{ }^{72}$ asserting that it had led the CJEU to change its jurisprudence in a more constitutionally oriented way. ${ }^{73}$ Indeed, Judgment No 232/1989 had been as inward-looking and dualistic as Judgment No 238/2014, and, through it, the No 238 of 2014 of the Italian Constitutional Court' [2014] Verfassungsblog on Constitutional Matters <http://verfassungsblog.de/know-wrong-just-cant-right-first-impressions-judgment238-2014-italian-constitutional-court/> accessed 20 February 2016. Judgment No 238/2014 (n 1) [3.4]; Kadi I (n 31).

71 Indeed, it is mainly thanks to this judgment that the figure of Ombudsperson for delisting was established by UNSC Res 1904 (17 December 2009) UN Doc S/RES/1904.

72 Italian Constitutional Court, Judgment No 232 (1989).

73 Judgment No 238/2014 (n 1) [3.4]. 
CJEU had similarly been threatened with 'counter-limits' - though these had not ultimately been used. Overall, the CC appears quite confident in its capacity to play some part in constitutionalising international law. ${ }^{74}$ The real intent of the CC in this regard is not completely clear. Further developments may clarify this still controversial point.

74 Note, though, that the Italian version of Judgment No 238/2014 is more forceful than its English translation. In the former, the CC affirms that the result of its review of the compatibility of the customary norm with the supreme constitutional principles shall be that of reducing the scope of the norm solely within the domestic order, and also asserts that this reduction 'is capable of [tale da] contributing' to a desirable evolution of international law. Compare with the English version: 'The result is a further reduction of the scope of this norm, with effects in the domestic legal order only. At the same time, however, this may also contribute to a desirable-and desired by many—evolution of international law itself'. See Judgment No 238/2014 (n 1) [3.3] (emphasis added). 